Abbreviated Key Title: Sch J Med Case Rep

ISSN 2347-9507 (Print) | ISSN 2347-6559 (Online)

Journal homepage: https://saspublishers.com

\title{
Metatarsal Stress Fracture: Different Imaging Aspects, a Case Report
}

M. Ouali Idrissi, A. Elhajjami*, B. Boutakioute, N. Idrissi Ganouni

Radiology Department, Arrazi Hospital, Mohammed VIth University Hospital Center, Caddi Ayyad University, Marrakech, Morocco

DOI: $10.36347 /$ sjmcr.2021.v09i04.036

| Received: 10.01.2021 | Accepted: 22.01.2021 | Published: 29.04.2021

*Corresponding author: Ayoub Elhajjami

Abstract

Case Report

Stress Fracture is a slightly common bone fracture that occurs due to disproportion of the mode of mechanic chronic stress and the strength of the bone. It can be Occur Either due to normal stress on diseased bones which called an insufficient fracture or due to strong stress on the normal bone which called a fatigue fracture.

Keywords: Stress Fracture bone fracture chronic stress.

Copyright $(\mathcal{C} 2021$ The Author(s): This is an open-access article distributed under the terms of the Creative Commons Attribution 4.0 International License (CC BY-NC 4.0) which permits unrestricted use, distribution, and reproduction in any medium for non-commercial use provided the original author and source are credited.

\section{CASE}

A 32 years old patient, presented with subacute foot pain with mild lameness, she has a history of ankle trauma 2 months ago with recent aggravation. The following are patient imaging.

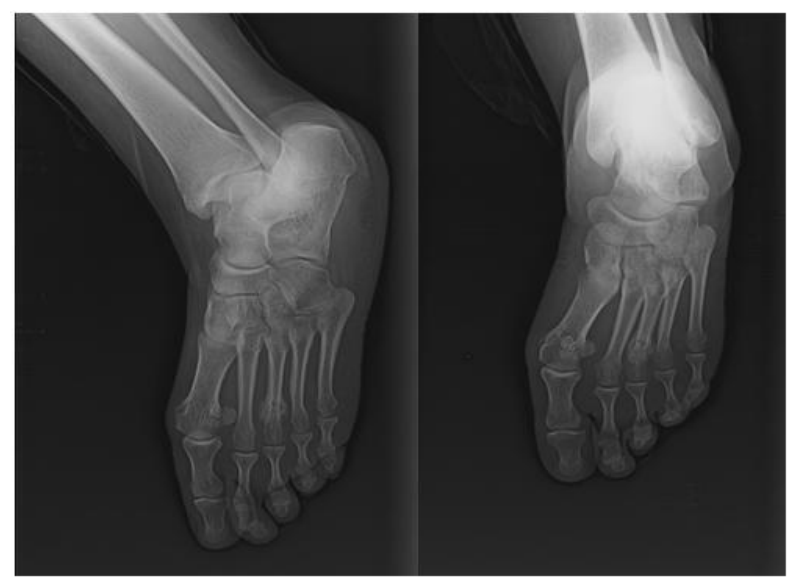

Xray Foot (AP and Lateral views) shows a periosteal reaction with a radiolucent transverse line in the distal third of the third metatarsal.
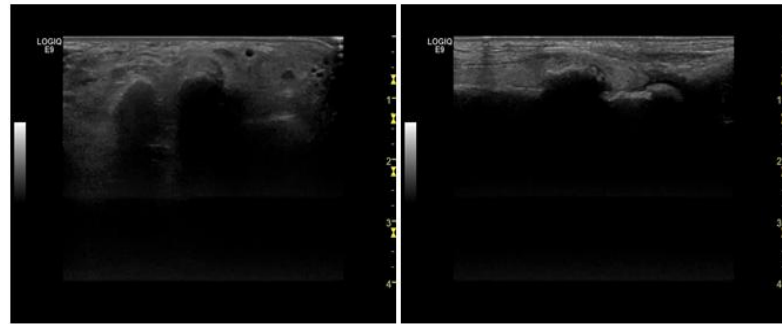

Ultrasound correlation of the fractured area revealed Hyperechogenic area with acoustic shadow

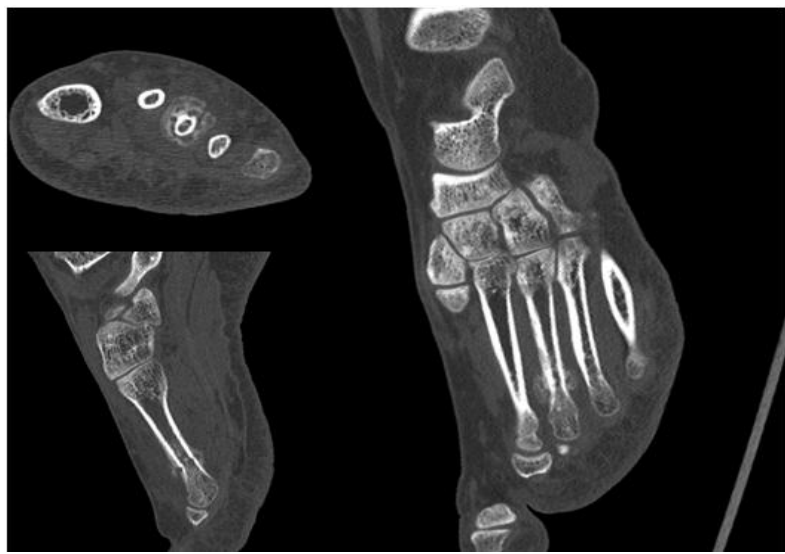

CT Bone show periosteal reaction with a radiolucent transverse line

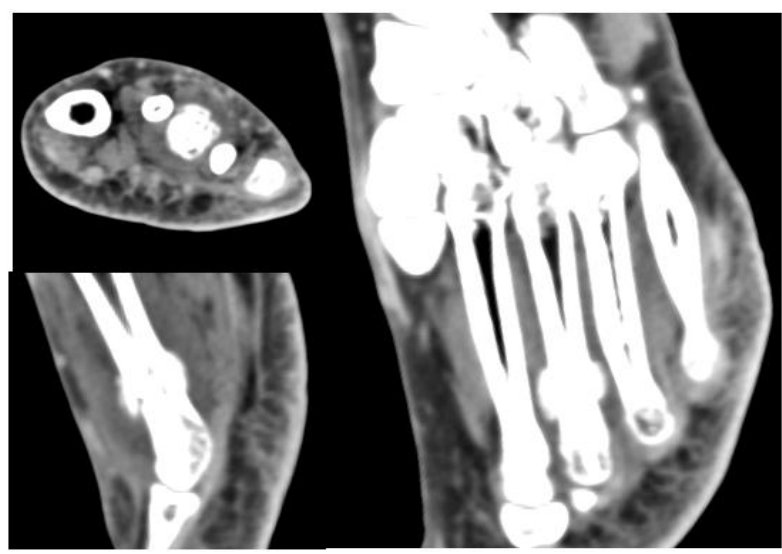

CT (Small parts) shows Small part edema

Citation: M. Ouali Idrissi et al. Metatarsal Stress Fracture: Different Imaging Aspects, a Case Report. Sch J Med Case Rep, 2021 Apr 9(4): 439-440. 


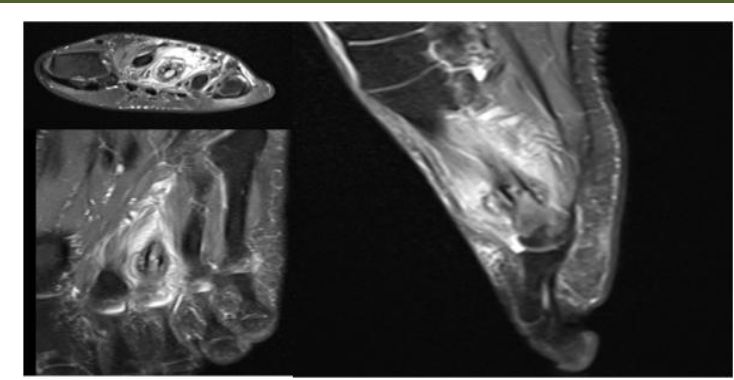

MRI (axial, coronal, and sagittal Proton Density shows Bone marrow edema low signal T1 hyperintense in T2 and STIR. Adjacent small parts edema.T1 hypointense fracture line.

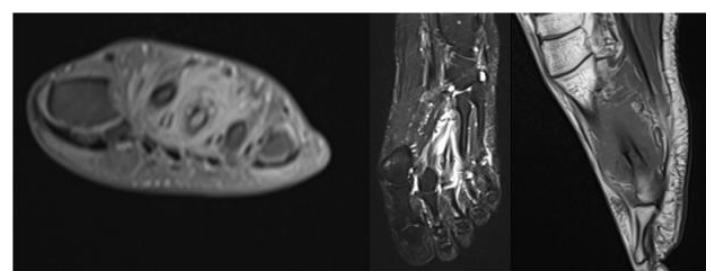

MRI T1 axial and sagittal and Coronal STIR show Bone marrow edema low signal T1 hyperintense in T2 and STIR. Adjacent small parts edema. T1 hypointense fracture line.

\section{DISCUSSION}

Second to fourth metatarsal bones are the most common site for a stress fracture in the foot, if the fracture occurs in the metatarsal neck it's called March fracture (called after soldier repeated stress fracture due to heavy marching) and it's a high-risk fracture to nonunion due to its poor vascularity. If it occurs in the metatarsal shaft it's a low-risk fracture as it has good vascularity. MRI is the most important imaging feature modality to differentiate between these two types [2, 5]. This case considered a low-risk fracture as it's in the shaft although that it should undergo follow up to exclude other complications.

About Imaging Findings of metatarsal Stress Fracture, Xray imaging has poor sensitivity although high specific for a stress fracture in the first weeks and it may take months to appear [6]. On Xray, Stress fracture appears as a hypodense fracture line surrounded by the periosteal reaction.

MRI Imaging is the most sensitive modality for a stress fracture, it appears as a T1 hypointense line surrounded by periosteal and bone marrow edema [9].

Nuclear Medicine is sensitive but not specific in the first days of stress fracture (although it's less sensitive than MRI), it appears as an increase in activity (Hot Spot) [7].

CT has a similar role of Xray and has similar features (fracture line, sclerosis, periosteal reaction, new bone formation), plus it can be helpful if Xray is a negative and positive bone scan [10].

Ultrasound has good sensitivity and less specificity in the diagnosis of metatarsal fracture plus general ultrasound features (Noninvasive, mobile, costless). Stress fracture appears on ultrasound sound as cortical disruption surrounded by hyper-echogenicity (soft tissue edema) and increases power doppler and periosteal thickening [1].

\section{RECOMMENDATION}

MRI is the recommended imaging modality for diagnosis of a stress fracture, if not available ultrasound plays a promising role in stress fracture diagnosis.

\section{REFERENCES}

1. Amoako A, Abid A, Shadiack A, Monaco R. Ultrasound-diagnosed tibia stress fracture: A case report. Clinical Medicine Insights: Arthritis and Musculoskeletal Disorders. 2017 Apr 7; 10:1179544117702866.

2. Berger FH, de Jonge MC, Maas M. Stress fractures in the lower extremity: the importance of increasing awareness amongst radiologists. European journal of radiology. 2007 Apr 1;62(1):16-26.

3. Elstrom JA, Virkus W, Pankovich AM. Handbook of fractures. McGraw Hill Professional; 2006.

4. Kaplan P. Musculoskeletal MRI. W B Saunders Co. ISBN: 0721690270. Read it at Google Books Find it at Amazon; 2001.

5. Marshall RA, Mandell JC, Weaver MJ, Ferrone M, Sodickson A, Khurana B. Imaging features and management of stress, atypical, and pathologic fractures. Radiographics. 2018 Nov;38(7):2173-92.

6. Bencardino JT, Stone TJ, Roberts CC, Appel M, Baccei SJ, Cassidy RC, Chang EY, Fox MG, Greenspan BS, Gyftopoulos S, Hochman MG. ACR Appropriateness Criteria ${ }^{\circledR}$ stress (fatigue/insufficiency) fracture, including sacrum, excluding other vertebrae. Journal of the American College of Radiology. 2017 May 1;14(5):S293306.

7. Kiuru MJ, Pihlajamaki HK, Hietanen HJ, Ahovuo JA. MR imaging, bone scintigraphy, and radiography in bone stress injuries of the pelvis and the lower extremity. Acta Radiologica.2002;43(2):207-12.

8. Matheson GO, Clement DB, McKenzie DC, Taunton JE, Lloydsmith DR, Macintyre JG. Stressfractures in athletes - a study of 320 cases. Am J Sports Med. 1987;15(1):46-58.

9. Arendt EA, Griffiths HJ. The use of MR imaging in the assessment and clinical management of stress reactions of bone in high-performance athletes. Clin Sports Med. 1997;16(2):291-306. 